\title{
Support for teaching "could boost university research'
}

London. A lack of investment has left British universities unable to meet the research demands being placed upon them, according to a report published this week by the National Academies Policy Advisory Group*, a body established jointly by Britain's leading academies of science, engineering, medicine, humanities and social science.

The group says that better support for university teaching would help the research side to develop properly by enabling universities to focus on their individual strengths. Indeed, it recommends that the funding councils responsible for allocating funds to universities should earmark about $£ 50$ million a year for professional development and teaching, using money drawn from elements of current research funding.

Its report adds to the mounting pressure on the UK government to increase capital spending on universities. But little significant government action is likely to be taken until after the Dearing Committee on Higher Education reports in 1997.

While pressing the government to recognize the urgent capital needs of universities, especially for libraries, modern equipment and building maintenance, the report stops short of demanding more money from the government for universities.

"We saw no point in simply asking the government for more money," says David Harrison, master of Selwyn College, Cambridge, and chairman of the working group. Rather, the report recommends that existing funds be reallocated to make the best use of resources, including the concentration of research funding.

The $£ 50$ million allocated to teaching development, for example, could come from funds used to support research gaining a score of two or less (out of five) in the funding councils' regular Research Assessment Exercise. This proposal is an attempt to curb 'mission drift' - the tendency for individual universities to pursue funds for research even if they lack the necessary resources to carry it out effectively.

By making this recommendation, the report takes a wider perspective than expected. "We are recommending a shift in funding from low quality research to high quality teaching," says Harrison. He acknowledges that some universities will gain and some will lose under such a shift, but believes that it would help each university to concentrate on what it does best.

Alistair MacFarlane, principal of Heriot-

*NAPAG is a body set up jointly by the British Academy, the Conference of Medical Royal Colleges, the Royal Academy of Conference of Medical Royal Colleges, the Royal Academy of
Engineering and the Royal Society. Copies of the report, Research Capability of the University System, are available from the publications department of the Royal Society, price $£ 20.00$.
Watt University, Edinburgh, and a member of NAPAG, says the working party endorsed the principle that engaging in research requires "some component of scholarship and research" while recognizing that the highest level of research requires a concentration of funding. The working group had aimed to reconcile the requirements of excellence in teaching and research.

Recent government cuts in university spending have put both teaching and research under great strain. But the pressure on teaching has grown enormously along

\section{IMAGE UNAVAILABLE FOR COPYRIGHT REASONS}

Class act: high quality teaching should gain funds from low quality research, report says.

with the rise in student/staff ratios. On average across all disciplines, they have risen from 11 to 15 between 1989 and 1994.

"Teaching should have a higher status and not be regarded as a poor relation to research," Harrison adds. By seeking to relieve teaching pressure, the proposal specifically addresses the need for teachers in universities to update and refresh themselves through scholarly activity.

The proposal also addresses the anxiety of universities that the present funding methodology is unbalanced. Michael Powell, senior administrative officer at the Committee of Vice-Chancellors and Principals, says that "at present there is an element in favour of promoting excellence in research, but nothing to enhance the status of teaching".

David Triesman, general secretary of the Association of University Teachers, says that he welcomes "every authoritative voice raised in the interest of funding high quality research because the reality is that the cuts in capital funding and revenue this year threaten to force the UK to the very bottom of the OECD league table".

The report does not recommend that research funding be shifted from low rated research to higher rated research. But Harrison believes that the group's proposals would improve the quality of research by concentrating research funding. Ruth Bell
Radioastronomers fight broadcasters' challenge in Italy

Munich. Italy's national research council, the CNR, has called on the government to protect the interests of Italian radioastronomers, who have effectively lost the use of a scientifically important waveband to commercial radio stations.

The post and telecommunications ministry last year introduced new regulations which, for the first time, allow radio stations access to the 1660-1670 $\mathrm{MHz}$ frequency, after they had been excluded from their previous frequency band following its reallocation to mobile telephone networks.

But this new frequency band is used by radioastronomers to measure emissions from galaxies, quasars and galactic sources such as molecular clouds. In compliance with international agreements, the new regulations give radioastronomers priority over the frequencies, and in principle licences are issued to radio stations only on condition that they immediately switch off if their broadcasts interfere with radioastronomy measurements.

And interfere they do. Lucia Padrielli, director of the CNR Institute of Radioastronomy in Bologna, says emissions from at least 20 different transmitters have been detected at the institute's radiotelescope site, and that strong pop music from these transmitters completely drowns out the faint signals from space.

But she says that complaints to the authorities are processed so slowly that it can take several months for transmitters to clear the wavebands. By this time, she says, "other stations have been given licences to take their place". Around a quarter of the institute's working time involves this frequency, she says.

Goliardo Tomassetti, a researcher at the institute, complains that no-one in Italy appears willing to take responsibility for the problem. Local licensing authorities say they act under instructions from the central ministry for post and telecommunications.

The ministry, in turn, says the interests of radioastronomers are protected by the law giving them priority rights to the frequencies. But commercial radio stations are now preparing to challenge this law, claiming the right to broadcast freely. The CNR is preparing a counterclaim.

The CNR last week mounted a major publicity campaign aimed at forcing the government to solve the current problem. If the government is let off the hook on this issue, says Tomassetti, it will have little incentive to take action to protect other frequencies that are important to radioastronomers. "It could be the end of radioastronomy in our country," he says.

Alison Abbott 